\title{
Pulsed Light: Challenges of a Non-Thermal Sanitation Technology in the Winemaking Industry
}

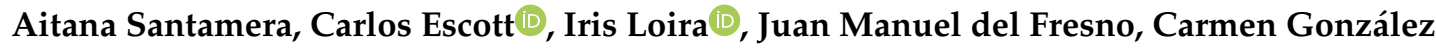 \\ and Antonio Morata *i
}

EnotecUPM, Chemistry and Food Technology Department, Universidad Politécnica de Madrid, Avenida Puerta de Hierro 2, 28040 Madrid, Spain; a.santamera@alumnos.upm.es (A.S.); carlos.escott@gmail.com (C.E.); iris.loira@upm.es (I.L.); juanmanuel.delfresno@upm.es (J.M.d.F.); carmen.gchamorro@upm.es (C.G.)

* Correspondence: antonio.morata@upm.es; Tel.: +34-910-671-127

Received: 6 June 2020; Accepted: 10 July 2020; Published: 14 July 2020

\begin{abstract}
Pulsed light is an emerging non-thermal technology viable for foodstuff sanitation. The sanitation is produced through the use of high energy pulses during ultra-short periods of time (ns to $\mu \mathrm{s}$ ). The pulsed light induces irreversible damages at the DNA level with the formation of pyrimidine dimers, but also produces photo-thermal and photo-physical effects on the microbial membranes that lead to a reduction in the microbial populations. The reduction caused in the microbial populations can reach several fold, up to $4 \log \mathrm{CFU} / \mathrm{mL}$ decrement. A slight increase of 3 to $4{ }^{\circ} \mathrm{C}$ in temperature is observed in treated food; nonetheless, this increase does not modify either the nutritional properties of the product or its sensory profile. The advantages of using pulsed light could be used to a greater extent in the winemaking industry. Experimental trials have shown a positive effect of reducing native yeast and bacteria in grapes to populations below 1-2 log CFU/mL. In this way, pulsed light, a non-thermal technology currently available for the sanitation of foodstuffs, is an alternative for the reduction in native microbiota and the later control of the fermentative process in winemaking. This certainly would allow the use of fermentation biotechnologies such as the use of non-Saccharomyces yeasts in mixed and sequential fermentations to preserve freshness in wines through the production of aroma volatile compounds and organic acids, and the production of wines with less utilization of $\mathrm{SO}_{2}$ in accordance with the consumers' demand in the market.
\end{abstract}

Keywords: antimicrobial; food technology; non-Saccharomyces; enzymatic activity; wine quality

\section{Introduction}

Pulsed light is composed of white light comprising the visible light spectrum and fractions of the ultraviolet and near infrared invisible light spectra [1] that can be obtained from different sources, with silica fibers doped with ytterbium ions $\left(\mathrm{Yb}^{3+}\right)$ being one of them [2]. This material is able to produce pulses with ultrashort durations (picoseconds and femtoseconds) and very high energy. Another source, commonly used in commercial equipment, is inert gases flash lamps filled with xenon or krypton [3]. Either way, the effects produced by a sequence of high intensity pulses has been tested in many different industrial fields.

Most of the initial experimental trials on the use of this technology were performed in the second half of the 20th century, in particular during the last three decades. The diversity of applications involving the use of pulsed light covers, to mention some, the thermal process of localized surfaces in semiconductors [4] without affecting the temperature of the overall device, or the possibility of sintering copper nanoparticles by replacing conventional thermal sintering, not suitable for the production of conductive lines, with a reactive sintering method for printed electronics with such a material [5]. 
In other distant field, the dermatology and cosmetic industries have also thoroughly evaluated the use of a variation of pulsed light technology with cut-off filters to select prescribed wavelengths [6] in treatments able to improve the aspect of the skin or to work as photo-rejuvenation [7] or promote collagen formation in upper dermal skin layers [8]; to work effectively on vascular facial lesions produced in patients with rosacea [9] or patients with facial hemangiomas [10]; to improve the state of stretch marks [11], and even to remove corporal hair in a long-term effective epilation process which is safe for people to use [12].

The effects that pulsed light have on biological structures have led to the use of this technology in other scopes. It has been observed that the energy released during the ultrashort emission treatments may affect protein structures and cellular membranes or even promote nucleic acid destruction and dimer formation [13]. These advantages have proven to work as alternatives for the reduction in pathogens from food matrices $[14,15]$ that have an impact, not only on the shelf life and quality of many foodstuffs intended for human consumption, but also on the health and safety demanded in these products.

This review provides up to date accessible information regarding this emerging non-thermal technology towards its utilization in the food industry, in particular its feasibility on the industrial usage and scale-up for grape and must sanitation in the winemaking industry.

\section{Pulsed Light Treatment Mechanism}

The energy involved in the pulsed light (PL) technology comprises the production of photons released by atoms when they are excited and then relaxed to a lower energy state. The photons could be emitted from a continuous light source or, in the case of PL, in pulses, the mechanism of which increases the energy, as the emission is produced in a short time [3]. The energy generated is stored in capacitors able to keep this energy over short periods of time-fractions of a second-and then release the energy over the surfaces to be treated [16]. The energy emitted in pulses is increased with this arrangement and it can be estimated to be several times the energy of the sun received by the surface of the planet at sea level [17].

One of the reasons why PL has antimicrobial properties is because the light emitted covers a wide range of the electromagnetic spectrum, especially the UV radiation. The PL energy covers from high frequency wavelengths in the UV spectrum $(\approx 200 \mathrm{~nm})$ to wavelengths in the near infrared spectrum $(2500 \mathrm{~nm})$ (Figure 1). The radiation corresponding to the UV spectrum includes all three wavelength ranges: long, medium and short, or UV-A, UV-B and UV-C, respectively [3].

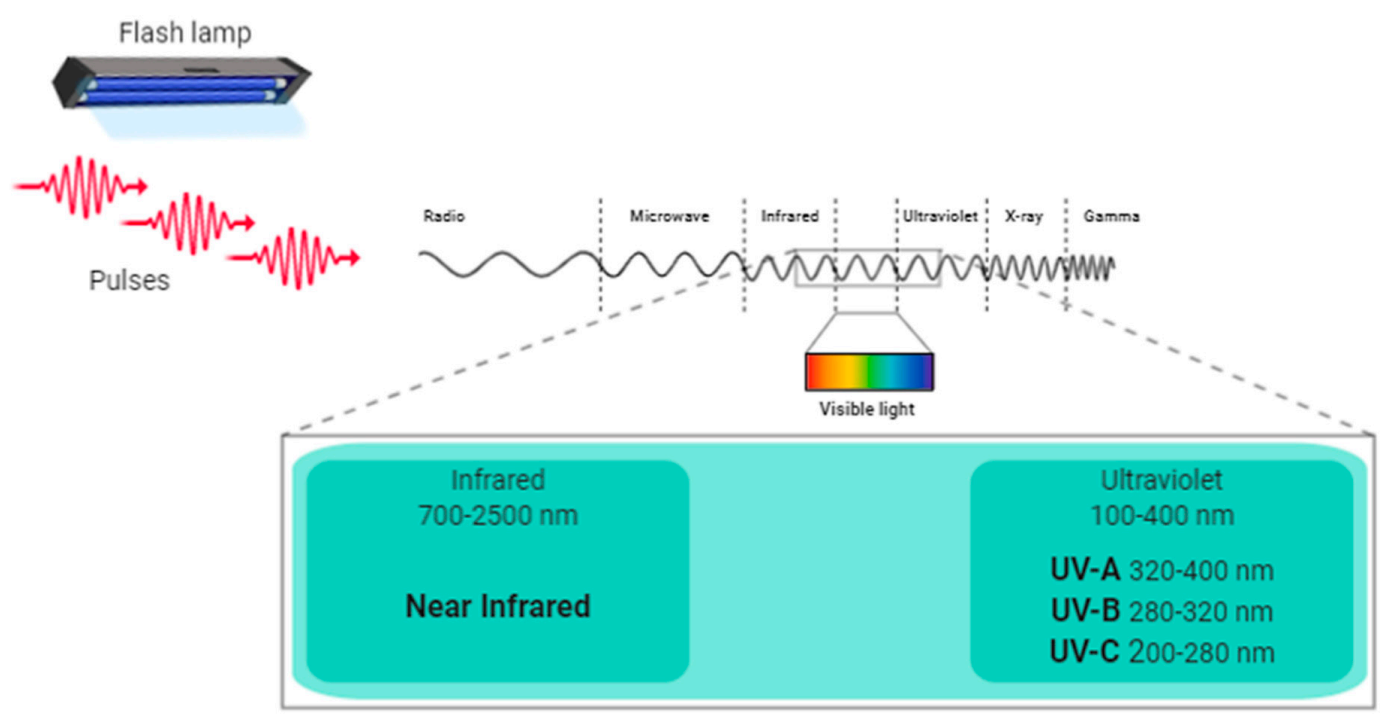

Figure 1. Range of the electromagnetic spectrum covered in the pulsed light (PL) irradiation. 
The UV-C light fraction from the PL radiation is mainly responsible for the inactivation of microorganisms found on the surface of the foodstuff, although UV-B and UV-A fractions can also contribute to microbial inactivation [18]. The UV-C light corresponds to the range of the electromagnetic spectrum between 200 and $280 \mathrm{~nm}$ [19]. The photochemical effect of the UV-C radiation (254-260 nm) is responsible for the formation of pyrimidine dimers, new covalent bonds previously non-existing in the polynucleotide chain, that inhibits the formation of new DNA chains needed for the cell replication $[16,19]$. The dimer formation occurs between adjacent thymine bases or between thymine and cytosine bases and inhibits the DNA replication. Although the principal consequence of the photochemical effect is the formation of dimers, there is also evidence on the occurrence of single-strand breaks and double-strand breaks of DNA's structure. Besides this photochemical effect, there might also be photo-thermal and photo-physical damage in the biological structures of yeast, bacteria and viruses when using PL. These damages include changes in membrane permeability, depolarization of the cell membrane, ion flow variations and localized heating [3] (Figure 2). At the same time, photo-induced degradation of phenolic compounds has been reported when PL treatments above $3.8 \mathrm{~J} / \mathrm{cm}^{2}$ are used in liquid media [20]. This suggests a potential reduction in secondary plant metabolites such as phenolic acids and flavonoids in uncontrolled treatments, with a subsequent reduction in the antioxidant capacity of the foodstuff.

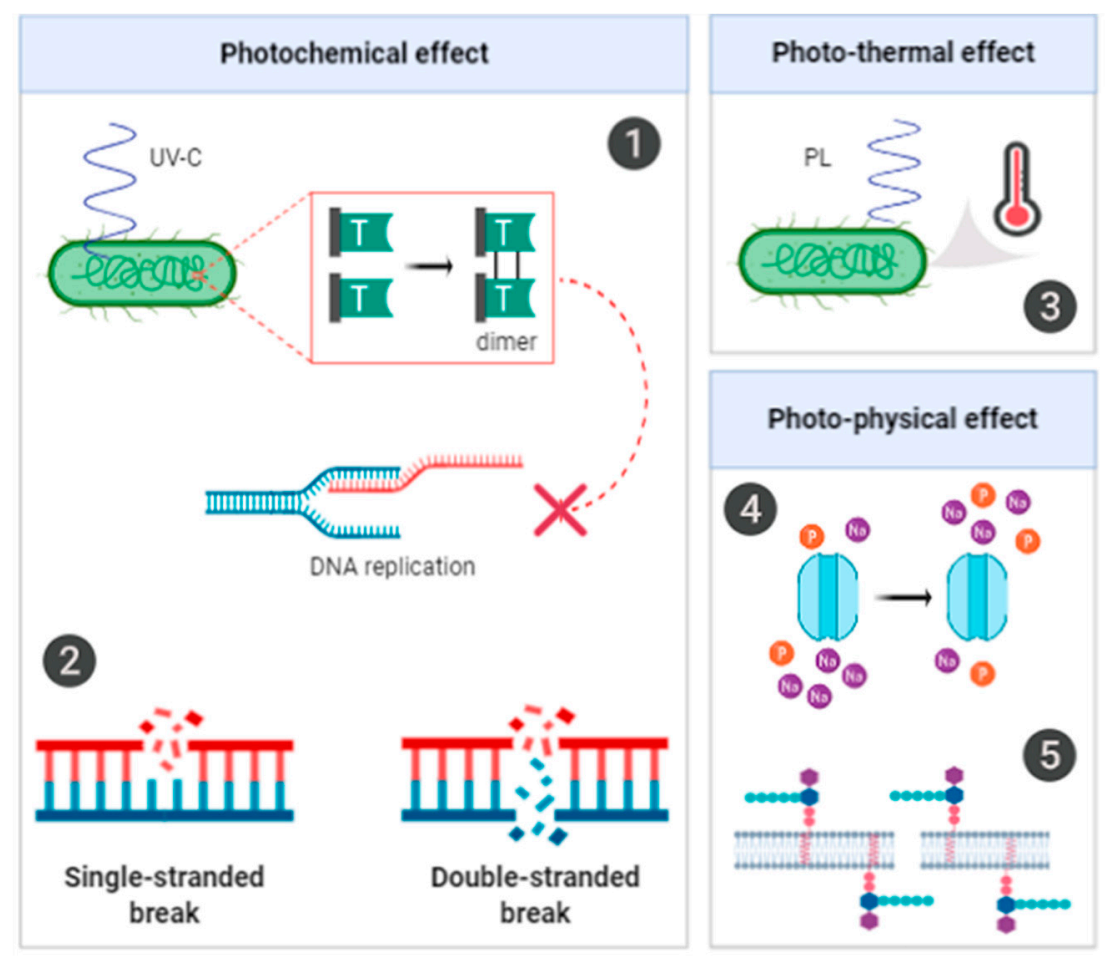

Figure 2. Photochemical, photo-thermal and photo-physical effects of UV-C radiation on microorganisms. (1) formation of dimers from adjacent thymines and inhibition of DNA replication, (2) single- and double-stranded breaks of DNA chains, (3) locally increased temperature, (4) ion flow modification and (5) membrane permeation.

In PL technology, for an efficient antimicrobial activity, it is critical to consider the number of pulses, the exposure time, and the dose or fluence that the product is receiving during the treatment, which is expressed as cumulative energy input $\left(\mathrm{J} / \mathrm{cm}^{2}\right)$ [21]. Dose-wise, there are several factors that influence this parameter since UV photons are less energetic than other photons; therefore, the distance between the flash lamp and the surface to be treated, the shading produce by the geometry of the sample and the micro-shading produced by the roughness of the surface and the discharge intensity are factors than can limit the effectiveness of treatments considering limited amount of pulses. The intensity of one emitted 
pulse can reach from 0.1 up to $50 \mathrm{~J} / \mathrm{cm}^{2}$ at the surface with up to 20 flashes per second [1]. Such a range would make it possible to use these pulses to inactivate microorganisms naturally found on foodstuff surfaces considering the FDA cumulative recommendation of $12 \mathrm{~J} / \mathrm{cm}^{2}$ for food treatments [22].

Even though there is a photo-thermal effect on biological structures produced locally, with temperature rising up to $130^{\circ} \mathrm{C}$, causing the rapid heating of microbial membranes [23], the overall thermal effect on particular food matrices can be considered negligible. PL together with other emerging technologies such high pressure processing (HPP) or high hydrostatic pressure (HHP), pulsed electric field (PEF) and e-beam irradiation are considered non-thermal technologies able to preserve food nutritional and organoleptic properties contrary to what is observed when using conventional thermal technologies [24]. Experimental trials using a pulsed light sterilization laboratory unit with two xenon flash lamps of 254 $\mathrm{mm}$ length and maximum energy of $6 \mathrm{kVA}$ have shown an increase in temperature between 3 and $4{ }^{\circ} \mathrm{C}$ (Figure 3). The increase in temperature observed on the surface of the berries would not imply an alteration of the sensory profile, nor would it change the nutritional properties either.

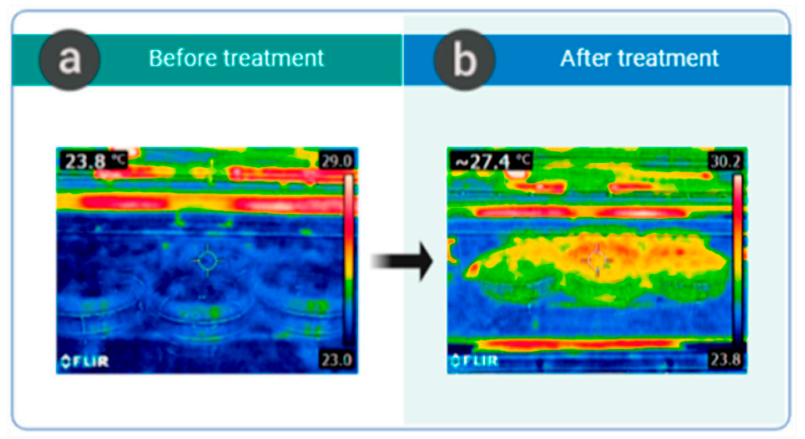

Figure 3. Temperature increase on the surface of table grapes after 5-pulses treatment. (a) temperature on the surface before pulses, and (b) temperature after pulses treatment.

Lastly, the use of PL may also imply having more energy efficient processes [25], as well as lower operative costs and minimal environmental impact [3], since there are no emissions of organic volatiles or suspended particles related to this emerging technology.

\section{Food Spoilage Microorganisms and Pathogens Elimination}

PL has been evaluated for the reduction in a wide variety of microorganisms located on the most outermost layer of non-processed products and others multiplied in crossed contamination during the transformation into ready-to-eat foodstuff. The control of microbial populations with PL includes reducing or eliminating spoilage yeasts, molds and bacteria $[26,27]$ and assuring the elimination of pathogens including Escherichia coli [28], Salmonella enterica [29] and Listeria monocytogenes [30,31], the virulent species of which are responsible for diseases such as gastroenteritis, salmonellosis and listeriosis. Foodborne pathogens are responsible for millions of illnesses around the world every year and thus, the number of deaths related to foodborne diseases and the health-related costs can be significant [32].

The effectiveness of PL in the reduction in pathogens and food spoilage microorganisms has been tested in several different foodstuff matrices in the last decades. The use of PL in fruits and vegetables, either on raw products or after any kind of food processing (slicing, cutting, etc.), is shown in Table 1, whilst Table 2 shows data regarding the microbial reduction observed in meat products. Information regarding the use of this sanitation technology in grapes, must and wine is still scarce and limited to a low number of publications. 
Table 1. Microbial reduction levels for fruits and vegetables after pulsed light treatment.

\begin{tabular}{|c|c|c|c|c|}
\hline Food Product & Microorganism & Processing Conditions & Reduction $(\log 10 \mathrm{CFU} / \mathrm{mL})$ & Reference \\
\hline \multirow{4}{*}{ Raspberry } & Escherichia coli O157:H7 & Total fluence $\left(\mathrm{J} / \mathrm{cm}^{2}\right): 28.2$ & 3.9 & \multirow{4}{*}[33]{} \\
\hline & Salmonella & Peak power $\left(\mathrm{J} / \mathrm{cm}^{2} /\right.$ pulse $): 1.27$ & 4.5 & \\
\hline & Total viable count & Exposure time (s): 30 & 1.5 & \\
\hline & Yeast and moulds & Distance from the lamp $(\mathrm{cm}): 13$ & 1.6 & \\
\hline Tomato fruit & $\begin{array}{l}\text { Microflora in skin and peduncle } \\
\text { Saccharomyces cerevisiae }\end{array}$ & $\begin{array}{c}\text { Total fluence }\left(\mathrm{J} / \mathrm{cm}^{2}\right): 4 \text { (microflora) and } 2.2 \\
(\text { Cerevisiae) } \\
\text { Pulse width }(\mu \mathrm{s}): 250 \\
\text { Discharge voltage }(\mathrm{V}): 2500\end{array}$ & $\begin{array}{c}1 \\
2.3\end{array}$ & {$[34]$} \\
\hline Avocado & $\begin{array}{l}\text { Aerobic mesophilic } \\
\text { microorganisms }\end{array}$ & $\begin{array}{c}\text { Total fluence }\left(\mathrm{J} / \mathrm{cm}^{2}\right): 14 \\
\text { Peak power }\left(\mathrm{J} / \mathrm{cm}^{2} / \mathrm{pulse}\right): 0.4 \\
\text { Pulse width }(\mu \mathrm{s}): 300 \\
\text { Distance from the lamp }(\mathrm{cm}): 5\end{array}$ & 1.2 & [35] \\
\hline Fresh-cut tomatoes & $\begin{array}{l}\text { Psychrophilic bacteria } \\
\text { Moulds and yeasts }\end{array}$ & $\begin{array}{c}\text { Total fluence }\left(\mathrm{J} / \mathrm{cm}^{2}\right): 4,6 \text { and } 8 \\
\text { Peak power }\left(\mathrm{J} / \mathrm{cm}^{2} / \text { pulse): } 0.4\right. \\
\text { Pulse width }(\mu \mathrm{s}): 300 \\
\text { Stored for } 20 \text { days at } 4{ }^{\circ} \mathrm{C}\end{array}$ & $\begin{array}{l}\text { Up to } 1.8 \\
\text { Up to } 0.5\end{array}$ & [36] \\
\hline Fresh-cut tomato & $\begin{array}{l}\text { Listeria innocua } \\
\text { Escherichia coli }\end{array}$ & $\begin{array}{c}\text { Total fluence }\left(\mathrm{J} / \mathrm{cm}^{2}\right): 4,6 \text { and } 8 \\
\text { Peak power }\left(\mathrm{J} / \mathrm{cm}^{2} / \text { pulse): } 0.4\right. \\
\text { Pulse width }(\mu \mathrm{s}): 300 \\
\text { Distance above and below from the lamp }(\mathrm{cm}): 8.5 \\
\text { Stored for } 20 \text { days at } 4{ }^{\circ} \mathrm{C}\end{array}$ & $\begin{array}{l}0.9 \\
1.4\end{array}$ & [28] \\
\hline \multirow{2}{*}{ Spinach leaves } & $\begin{array}{l}\text { Listeria innocua } \\
\text { Escherichia coli }\end{array}$ & $\begin{array}{c}\text { Total fluence }\left(\mathrm{J} / \mathrm{cm}^{2}\right): 0.8 \\
\text { Peak power }\left(\mathrm{J} / \mathrm{cm}^{2} / \mathrm{pulse}\right): 0.4 \\
\text { Pulse width }(\mu \mathrm{s}): 300 \\
\text { Distance from the lamp }(\mathrm{cm}): 8.5\end{array}$ & $\begin{array}{l}1.85 \\
1.72\end{array}$ & \multirow[t]{2}{*}{ [26] } \\
\hline & $\begin{array}{l}\text { Mesophilic aerobic bacteria } \\
\text { Psychrotrophic bacteria } \\
\text { Coliforms } \\
\text { Listeria ssp } \\
\text { Yeast and moulds }\end{array}$ & $\begin{array}{c}\text { Total fluence }\left(\mathrm{J} / \mathrm{cm}^{2}\right): 4 \\
\text { Pulse width }(\mu \mathrm{s}): 300 \\
\text { Distance from the lamp }(\mathrm{cm}): 8.5\end{array}$ & $0.5-2.2$ & \\
\hline
\end{tabular}


Table 1. Cont

\begin{tabular}{|c|c|c|c|c|}
\hline Food Product & Microorganism & Processing Conditions & Reduction $(\log 10 \mathrm{CFU} / \mathrm{mL})$ & Reference \\
\hline Fresh-cut apple slices & $\begin{array}{l}\text { Mesophilic and psychrophilic } \\
\text { aerobic bacteria } \\
\text { Moulds and yeasts }\end{array}$ & $\begin{array}{c}\text { Total fluence }\left(\mathrm{J} / \mathrm{cm}^{2}\right): 16 \\
\text { Peak power }\left(\mathrm{J} / \mathrm{cm}^{2} / \mathrm{pulse}\right): 0.4 \\
\text { Pulse width }(\mu \mathrm{s}): 300 \\
\text { Distance above and below from the lamp }(\mathrm{cm}): 8.5\end{array}$ & $\begin{array}{l}1.55 \\
2.3\end{array}$ & {$[27]$} \\
\hline Fresh-cut apple slices & $\begin{array}{l}\text { Total viable counts } \\
\text { Lactobacillus brevis } \\
\text { Listeria monocytogenes }\end{array}$ & $\begin{array}{c}\text { Number of pulses: } 9 \\
\text { Peak power }\left(\mathrm{J} / \mathrm{cm}^{2} / \text { pulse): } 1.75\right. \\
\text { Pulse width }(\mu \mathrm{s}): 500 \\
\text { Distance from the lamp }(\mathrm{cm}): 1\end{array}$ & $\begin{array}{l}1.0 \\
3.0 \\
2.7\end{array}$ & {$[30]$} \\
\hline Cherry tomato & Salmonella enterica & $\begin{array}{c}\text { Total fluence }\left(\mathrm{J} / \mathrm{cm}^{2}\right): 31.5 \\
\text { Peak power }\left(\mathrm{J} / \mathrm{cm}^{2} / \text { pulse }\right): 0.35 \\
\text { Pulse width }(\mu \mathrm{s}): 500 \\
\text { Exposure time }(\mathrm{s}): 30 \\
\text { Distance from the lamp }(\mathrm{cm}): 14\end{array}$ & 2.3 & [29] \\
\hline $\begin{array}{l}\text { Fresh-cut cucumber } \\
\text { slices }\end{array}$ & Escherichia coli ATCC 26 & $\begin{array}{c}\text { Total fluence }\left(\mathrm{J} / \mathrm{cm}^{2}\right): 12 \\
\text { Peak power }\left(\mathrm{J} / \mathrm{cm}^{2} / \mathrm{pulse}\right): 0.43 \\
\text { Pulse width }(\mu \mathrm{s}): 360 \\
\text { Exposure time }(\mathrm{s}): 12.4 \\
\text { Distance from the lamp }(\mathrm{cm}): 10.8\end{array}$ & 2.8 & [37] \\
\hline $\begin{array}{l}\text { Fresh-cut avocado, } \\
\text { watermelon and } \\
\text { mushrooms }\end{array}$ & $\begin{array}{l}\text { Escherichia coli } \\
\text { Listeria innocua }\end{array}$ & $\begin{array}{c}\text { Total fluence }\left(\mathrm{J} / \mathrm{cm}^{2}\right): 12 \\
\text { Peak power }\left(\mathrm{J} / \mathrm{cm}^{2} / \text { pulse): } 0.4\right. \\
\text { Pulse width }(\mu \mathrm{s}): 300 \\
\text { Distance from the lamp }(\mathrm{cm}): 8.5\end{array}$ & $\begin{array}{l}2.58,2.88 \text { and } 2.97 \\
2.25,2.17 \text { and } 3.62\end{array}$ & [38] \\
\hline $\begin{array}{l}\text { Strawberries (S) and } \\
\text { blueberries (B) }\end{array}$ & $\begin{array}{c}\text { Murine norovirus (MNV-1) } \\
\text { Escherichia coli } \\
\text { Salmonella }\end{array}$ & $\begin{array}{c}\text { Total fluence }\left(\mathrm{J} / \mathrm{cm}^{2}\right): 22.5 \\
\text { Exposure time }(\mathrm{s}): 24 \\
\text { Number of pulses: } 16 \\
\text { Distance from the lamp }(\mathrm{cm}): 16\end{array}$ & $\begin{array}{l}\text { S: } 0.9 \text { B: } 3.8 \\
\text { S: } 1.9 \text { B: } 5.7 \\
\text { S: } 2.1 \text { B: } 4.2\end{array}$ & [39] \\
\hline Blueberries & Salmonella & $\begin{array}{l}\text { Total fluence }\left(\mathrm{J} / \mathrm{cm}^{2}\right): 6 \\
\text { Peak power }\left(\mathrm{J} / \mathrm{cm}^{2} / \mathrm{pulse}\right): 0.066 \\
\text { Pulse width }(\mu \mathrm{s}): 360 \\
\text { Exposure time }(\mathrm{s}): 30\end{array}$ & $\begin{array}{l}0.9 \text { spot inoculation } \\
0.6 \text { dip inoculation }\end{array}$ & {$[40]$} \\
\hline
\end{tabular}


Table 1. Cont.

\begin{tabular}{|c|c|c|c|c|}
\hline Food Product & Microorganism & Processing Conditions & Reduction $(\log 10 \mathrm{CFU} / \mathrm{mL})$ & Reference \\
\hline \multirow{2}{*}{ Fresh-cut lettuce } & $\begin{array}{l}\text { Salmonella enteritidis } \\
\text { Escherichia coli } \\
\text { Staphylococcus aureus } \\
\text { Listeria monocytogenes }\end{array}$ & $\begin{array}{c}\text { Total fluence }\left(\mathrm{J} / \mathrm{cm}^{2}\right): 16.8 \\
\text { Peak power }\left(\mathrm{J} / \mathrm{cm}^{2} / \text { pulse): } 0.33\right. \\
\text { Pulse width }(\mu \mathrm{s}): 300 \\
\text { Exposure time }(\mathrm{s}): 25 \\
\text { Distance from the lamp }(\mathrm{cm}): 9\end{array}$ & $\begin{array}{l}5.40 \\
5.08 \\
6.56 \\
4.00\end{array}$ & \multirow{2}{*}[31]{} \\
\hline & $\begin{array}{l}\text { Total bacteria count } \\
\text { Yeast and moulds }\end{array}$ & $\begin{array}{c}\text { Total fluence }\left(\mathrm{J} / \mathrm{cm}^{2}\right): 4-16.8 \\
\text { Peak power }\left(\mathrm{J} / \mathrm{cm}^{2} / \text { pulse): } 0.33\right. \\
\text { Pulse width }(\mu \mu \mathrm{s}): 300 \\
\text { Exposure time }(\mathrm{s}): 6-25 \\
\text { Distance from the lamp }(\mathrm{cm}): 9\end{array}$ & $\begin{array}{l}2.73 \\
1.14\end{array}$ & \\
\hline Raspberries & $\begin{array}{l}\text { Salmonella Newport } \\
\text { Escherichia coli }\end{array}$ & $\begin{array}{c}\text { Total fluence }\left(\mathrm{J} / \mathrm{cm}^{2}\right): 14.3 \\
\text { Peak power }\left(\mathrm{J} / \mathrm{cm}^{2} / \mathrm{pulse}\right): 1.27 \\
\text { Exposure time (s): } 15\end{array}$ & $\begin{array}{l}3.4 \\
3.3\end{array}$ & [41] \\
\hline Green onion & Escherichia coli & $\begin{array}{c}\text { Total fluence }\left(\mathrm{J} / \mathrm{cm}^{2}\right): 5 \\
\text { Peak power }\left(\mathrm{J} / \mathrm{cm}^{2} / \text { pulse): } 1.27\right. \\
\text { Exposure time (s): } 5\end{array}$ & $\begin{array}{c}\text { Spot inoculation: stems } 4.8 \\
\text { and leaves } 4.1 \\
\text { Dip inoculation: stems } 0.2 \\
\text { and leaves } 0.6\end{array}$ & [42] \\
\hline
\end{tabular}

Table 2. Microbial reduction levels for meat after pulsed light treatment.

\begin{tabular}{|c|c|c|c|c|}
\hline Food Product & Microorganism & Treatment & Reduction $(\log 10 \mathrm{CFU} / \mathrm{mL})$ & Reference \\
\hline $\begin{array}{l}\text { Serrano ham slices } \\
\text { Iberian ham slices }\end{array}$ & Listeria іппосиа & $\begin{array}{l}\text { Total fluence }\left(\mathrm{J} / \mathrm{cm}^{2}\right): 0,2.1,4.2 \text { and } 8.4 \\
\text { Peak power }\left(\mathrm{J} / \mathrm{cm}^{2} / \mathrm{pulse}\right): 0.3 \\
\text { Stored for } 4 \text { days at } 20^{\circ} \mathrm{C}\end{array}$ & $\begin{array}{l}1 \\
2\end{array}$ & [43] \\
\hline Pork loin & \multirow{2}{*}{$\begin{array}{l}\text { Salmonella typhimurium } \\
\text { Yersinia enterocolitica }\end{array}$} & $\begin{array}{c}\text { Total fluence }\left(\mathrm{J} / \mathrm{cm}^{2}\right): 0.52-19.11 \\
\text { Peak power }\left(\mathrm{J} / \mathrm{cm}^{2} / \mathrm{puse}\right): 1.27 \\
\text { Pulse width }(\mu \mathrm{s}): 300 \\
\text { Exposure time }(\mathrm{s}): 1-30 \\
\text { Distance from the lamp }(\mathrm{cm}): 8.3-13.4\end{array}$ & $\begin{array}{c}0.4-1.71 \\
0.39-1.69\end{array}$ & \multirow[t]{2}{*}{ [44] } \\
\hline Pork skin & & $\begin{array}{c}\text { Total fluence }\left(\mathrm{J} / \mathrm{cm}^{2}\right): 19.11 \\
\text { Peak power }\left(\mathrm{J} / \mathrm{cm}^{2} / \mathrm{pulse}\right): 1.27 \\
\text { Pulse width }(\mu \mathrm{s}): 300 \\
\text { Exposure time }(\mathrm{s}): 30 \\
\text { Distance from the lamp }(\mathrm{cm}): 8.3\end{array}$ & $\begin{array}{l}2.97 \\
4.19\end{array}$ & \\
\hline
\end{tabular}


A direct consequence of the reduction in spoilage microorganisms in foodborne products is an increase in the shelf-life of fresh products. The shelf-life of products may be extended by preventing deterioration and looking forward to maintaining organoleptic properties [45]. However, depending on the foodstuff and the PL treatment, a negative impact in organoleptic properties may appear; such is the case of the negative modification of sensory properties of bologna with $2.1 \mathrm{~J} / \mathrm{cm}^{2}$ treatment, while the use of $8.4 \mathrm{~J} / \mathrm{cm}^{2}$ did not produce sensory changes in cooked ham [46]. Products such as fresh-cut fruits and vegetables, fruit juices, meat, fish and derivative products (beef, tuna, salmon) are examples of extended shelf-life after the use of PL treatments [47]. The proper use of food preservation technologies and proper food packaging materials would contribute to extending the products shelf-life.

The use of PL is recommended for packaged foodstuff since this technology does not leave any residues, as is the case for the formation of hydrogen peroxide $\left(\mathrm{H}_{2} \mathrm{O}_{2}\right)$ or peracetic acid $\left(\mathrm{CH}_{3} \mathrm{CO}_{3} \mathrm{H}\right)$ [24]. Nonetheless, there are contrary opinions in this regard; while some authors suggested the use of PL to decontaminate food packed products [47], there are other opinions that consider that there is a drawback in the use of this technology, since the packaging of foods treated with PL shall need aseptic conditions prior to packaging the product and then continue with the decontamination process [21]. This means that the whole process has to comply with sterilization standards for processing equipment and packaging containers to avoid cross-linked contamination of any kind.

\section{Use of Pulsed Light for Grape Sanitation}

The effectiveness of PL is higher when applied on surfaces than on liquids [48]. This entails that it is easier to apply the PL on grapes before crushing them to produce must or juice. The effect of PL as a treatment for the reduction in microbial populations in grapes has been evaluated, although the negative effect produced on microorganisms caused by the use of UV-C light, component also present in the PL flashes, was proven even before in various fruit matrices [49-51].

Despite the scarce experimental evidence on the use of PL on Vitis vinifera for sanitation purposes, there are data on laboratory-scale trials performed with two different energy doses, 300 and $600 \mathrm{~J}$, providing an energy density of 1.1 and $2.1 \mathrm{~J} / \mathrm{cm}^{2}$, respectively [52]. The results obtained have shown effectiveness in the reduction in both yeast and bacteria naturally found on the surface of Vitis vinifera $\mathrm{L}$. cv. Tempranillo. The treatment involved either 5 or 10 flashes (pulses) at each energy and the outcome has revealed more efficiency against bacteria populations, most probably due to being the largest population, when using the maximum energy possible regardless of the amount of pulses. Other studies have used different treatment set ups with less energy density on different fruit matrices. This is the case observed in trials intended for the elimination of Botrytis cinerea inoculated on strawberries [53]. One of the treatments involved pulsed light and combinations with heat and UV-C with an energy density of $0.05-0.1 \mathrm{~J} / \mathrm{cm}^{2}\left(0.5-1 \mathrm{~kJ} / \mathrm{m}^{2}\right)$ in pulses of 40 and $120 \mathrm{~s}$. PL at this low energy density did not affect the growth of mycelia, while combinations of PL and UV-C radiation delayed the spoilage caused by B. cinerea $24 \mathrm{~h}$. It is then observed that flashes emitted during shorter periods of time and higher energy density would increase the effectiveness of the irradiation to avoid the development of spoilage organisms located on food surfaces.

The effect of PL is expected to be more effective on the outer layers of grapes where the pruina, a waxy film covering the berries, and the microorganisms are located. The skin of the berries is therefore expected to undergo any sort of damage as well. On this matter, Fava et al. have demonstrated that the UV-C light is capable of producing damages on the epicarp and the mesocarp of grapes [54]. The disruption caused by the treatment was observed on epidermal cell walls and even deeper, on collenquimatous subepidermal layers. As anthocyanins, red-like molecules responsible for the colour of grapes and other berries, are produced in the cytosol of epidermal cells of the berries and stored in vacuoles, the use of PL pulses is expected to increase the release of these colored molecules during maceration in winemaking. The transfer of pigments from the skin to the pulp has been documented for variety Tempranillo red grapes after PL treatment [55]; nonetheless, the visual effect 
observed in the berries does not have an influence on the pigment and phenolic content from wines without treatment.

Static treatments produced in batch-size laboratory cabinets, where grapes do not have free movement during flashes, reduce the frequency of damages on the epidermis and vacuoles of grapes. As a result, even though it seems that there is an increase in pigment extraction in grape musts after PL treatment, the analytical evaluation does not show statistical differences among treated and non-treated grapes [52]. The use of roller bed conveyor belts for PL sanitation of grapes may increase the incidence of disruptions on the epidermal cells of the berries with the potential increment of pigment extraction.

\section{Influence of Pulsed Light on the Implantation of Non-Saccharomyces Yeasts in Musts}

The elimination of native microbiota in fruits have industrial potential applications other than providing safe food for human consumption by the elimination of pathogens. In this way, biotechnological processes may be used not only to control the transformation of raw products into ready-to-eat meals, but also to design the organoleptic profile these products are to have. The sanitation of vinification grapes with PL enables the use of selected starters from commercial yeast and bacteria strains to ensure the population load and to reduce the use of $\mathrm{SO}_{2}$ in wine $[52,56]$. Non-Saccharomyces yeasts are known for having low fermentation efficiency and having low ethanol yield [57-59]. They account for most of the yeast species found naturally on the skin of grapes (40 to 100), but their metabolic characteristics make them prone to disappearing at early fermentative phases in spontaneous or uninoculated fermentations, or when Saccharomyces cerevisiae strains are inoculated to assure their rapid dominance, and therefore the contribution of non-Saccharomyces yeasts to wine is minimized [60].

The so called non-conventional yeasts or non-Saccharomyces yeasts contribute to enhancing the aroma complexity in wines and are able to increase the yield in which desired fermentative compounds are produced $[61,62]$. The reasons attributed to non-Saccharomyces yeasts to perform this way are an increased production and releasing of enzymes and the high production of aromatic volatile compounds $[63,64]$. The enzymes involved in this enhancement include lipases, proteases, esterases and $\beta$-glycosidases; the aroma compounds are mainly esters and higher alcohols.

The reduction in native biota from the grape's pruina during grape sanitation with PL would allow winemakers to direct fermentations towards more customized wines. The reduction in microbiota is larger when PL is applied in comparison to sulphitation levels between 40 and $50 \mathrm{mg} / \mathrm{L}$ (Figure 4.). In a sulphited must, the reduction in wild yeasts would allow $S$. cerevisiae to implant and be the dominant species, since it is more resistant to $\mathrm{SO}_{2}$ [65]. The fact that the reduction in yeasts is larger when applying PL favors the implantation of non-Saccharomyces yeasts.

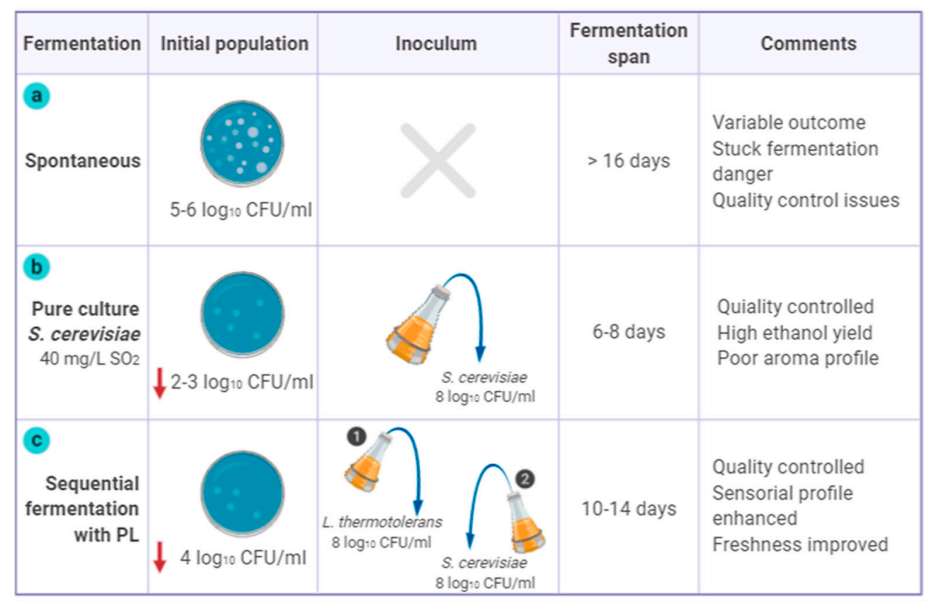

Figure 4. Summarized conditions comparison for three different fermentation scenarios: (a) spontaneous fermentation, (b) conventional pure culture fermentation with sulphited must and (c) sequential fermentation using grapes previously sanitized with PL treatment. Adapted from [52,60,62,66-69]. 


\section{Repercussion of Pulsed Light in the Wine Freshness}

In the context of global warming, there is a growing interest in improving the sensory perception of wines to counteract the harsh conditions of harvesting grapes in hot climate areas. Temperature changes and shifts in rainfall patterns would force the cultivars to thrive under such conditions. Higher temperatures will modify the chemistry of the grapes towards more sugar and less acid content, especially malic acid [70]. As a consequence, overripe grapes may produce wines with high alcohol content. The negative effects that global warming and climate change have on wines are perceived as inappropriate anthocyanin concentration affecting colour, imbalanced ratio of organic acids leading to tartaric acid addition to assure mouthfeel and microbial stability, and the potential production of odd overcooked aromas [71].

Actions to alleviate the negative impact of climate change include the use of elicitors applied to the canopy of vines. Elicitors, molecules able to activate secondary biosynthetic pathways in plants for self-protection, are used to try to reduce the differences in technological and physiological maturity of grapes by promoting a more rapid accumulation of phenolic compounds [72]. Another approach that promotes the formation of bioactive compounds is the use of PL in post-harvest products as an attempt to improve the quality of immature fruits such as tomatoes [73]. In this case, and contrary to what is aimed with the use of elicitors, the effect of PL is produced after the vegetative growth and once the fruits are harvested. Other approaches to diminish the negative impact of climate change involve the use of biotechnological solutions to help in reducing the alcohol content in wines, and therefore, the vinous or alcoholic perception of wines. These approaches consider using yeast strains with reduced glycolytic metabolism, yielding lower ethanol concentration in wines [59].

The freshness in wines is often perceived as a combination of parameters that all together contribute to increasing the fruity and floral scents and the acid character of wines. The aroma profile associated to freshness is produced by either fermentative metabolites, mainly esters, or by terpenic or thyolic precursors related to certain grape varieties released by yeast enzymatic activity [68]. Examples of such yeast strains cover the genera Torulaspora, Wickerhamomyces, Metschnikowia, Lachancea and Hanseniaspora, among others. Since these non-Saccharomyces yeast species have low-medium fermentative performance, the approach would consider mixed or sequential fermentations. Co-fermentations of Saccharomyces cerevisiae with Hanseniaspora vineae and Metschnikowia pulcherrima increases the total amount of acetate esters, ethyl esters and isoprenoids in wines [74]. The same Hanseniaspora vineae species has been proven to produce benzenoid compounds [75], as well as phenylpropanoid-derived compounds [76], capable of improving varietal and fermentative aromas of wines due to genetic variations in the enzymatic conformation in yeast strains. The fruity and floral contribution of these volatile compounds is noticed during the vinification process and so is the vanilla, woody or sweet coconut scents observed over the ageing period coming from hydroxybenzyl compounds produced from the metabolism of phenylpropanoids [75].

The acidic profile of wines can also be modified through yeast action, especially with the use of non-Saccharomyces yeast able to produce larger amounts of organic acids than conventional Saccharomyces cerevisiae strains commercially available. Such is the case of the yeast species Lachancea thermotolerans, known for its ability to consume and ferment glucose and fructose, and to assimilate galactose [77], but also known for its capability to produce lactic acid in a broad range of concentrations from 1 to $16.8 \mathrm{~g} / \mathrm{L}$ [78]. This yeast species is able to reduce $\mathrm{pH}$ values in more than 0.5 units in a metabolic natural way. A reduction in $\mathrm{pH}$ values would also increase the effectiveness of molecular $\mathrm{SO}_{2}$ added in lower dosages of total sulphites towards microbial stability in hot climate areas. Wines, mostly red wines and a few white wines, undergo malolactic fermentation (MLF) to reduce the amount of malic acid by a microbiological process performed by lactic acid bacteria strains of the genera Lactobacillus and Oenococcus $[79,80]$. The MLF usually takes place after the alcoholic fermentation (AF) and it usually needs special conditions for it to develop spontaneously; in most cases, the use of starter cultures is recommended. Among the reasons why the MLF is delayed or inhibited might be the concentration of lactic acid produced by yeast strains. High amounts of lactic acid produced by 
L. thermotolerans may inhibit the growth of lactic acid bacteria such as $O$. oeni and therefore complicate the reduction in malic acid through MLF [81]. To counteract this drawback, the co-fermentation of L. thermotolerans and $O$. oeni has shown synergetic interactions towards the production of lactic acid through both metabolic pathways and, thus, achieving the reduction in $\mathrm{pH}$ values and the decrease in malic acid concentration in wines [82].

In terms of colour, the sensory profile can be influenced by the intensity and the colour hue. Red wines with red-brown hues are associated with oxidized processes and thus with aged or old wines [68]. On the contrary, bright red and blue-violet tones resemble young and fresher wines. In this way, colour may also contribute to creating a perception of freshness in wines. The production of colored molecules through the interaction of anthocyanins and metabolites during fermentation is also linked to yeast activity. Non-Saccharomyces yeasts contribute to the formation of pyranoanthocyanin pigments and oligomeric and polymeric adducts [64]. The formation of oligomers through the condensation of ethyl-bridged adducts of anthocyanins and flavan-3-ols produces molecules with absorption wavelengths of ca. $540 \mathrm{~nm}$, towards red-blue hues [83]. The fermentation carried out completely with non-Saccharomyces yeasts seems to promote the formation of more oligomeric pigments than co-fermentations with S. cerevisiae [84]. There are several other molecular structures formed during ageing with wavelength absorbances higher than $530 \mathrm{~nm}$, as in the case of A-type portisins with blue hues [85]. These last pigments involve acetaldehyde moieties in their molecular structure, vinyl linkages, favored by microbial activity through an increased production of this fermentative metabolite.

Taking into account the abovementioned contributions that non-Saccharomyces yeasts may have to modulate freshness, it is of great importance to assure and control the implantation of yeast strains, and eventually bacteria strains, capable of modifying the sensory profile of wines. An overview with the benefits of the use of PL at winemaking facilities is available in Figure 5. The possibility of applying PL in situ at a winemaking facility, with the use of automated roller bed conveyors, can ease the sanitation of grapes and the implementation of the hereinabove mentioned biotechnologies.

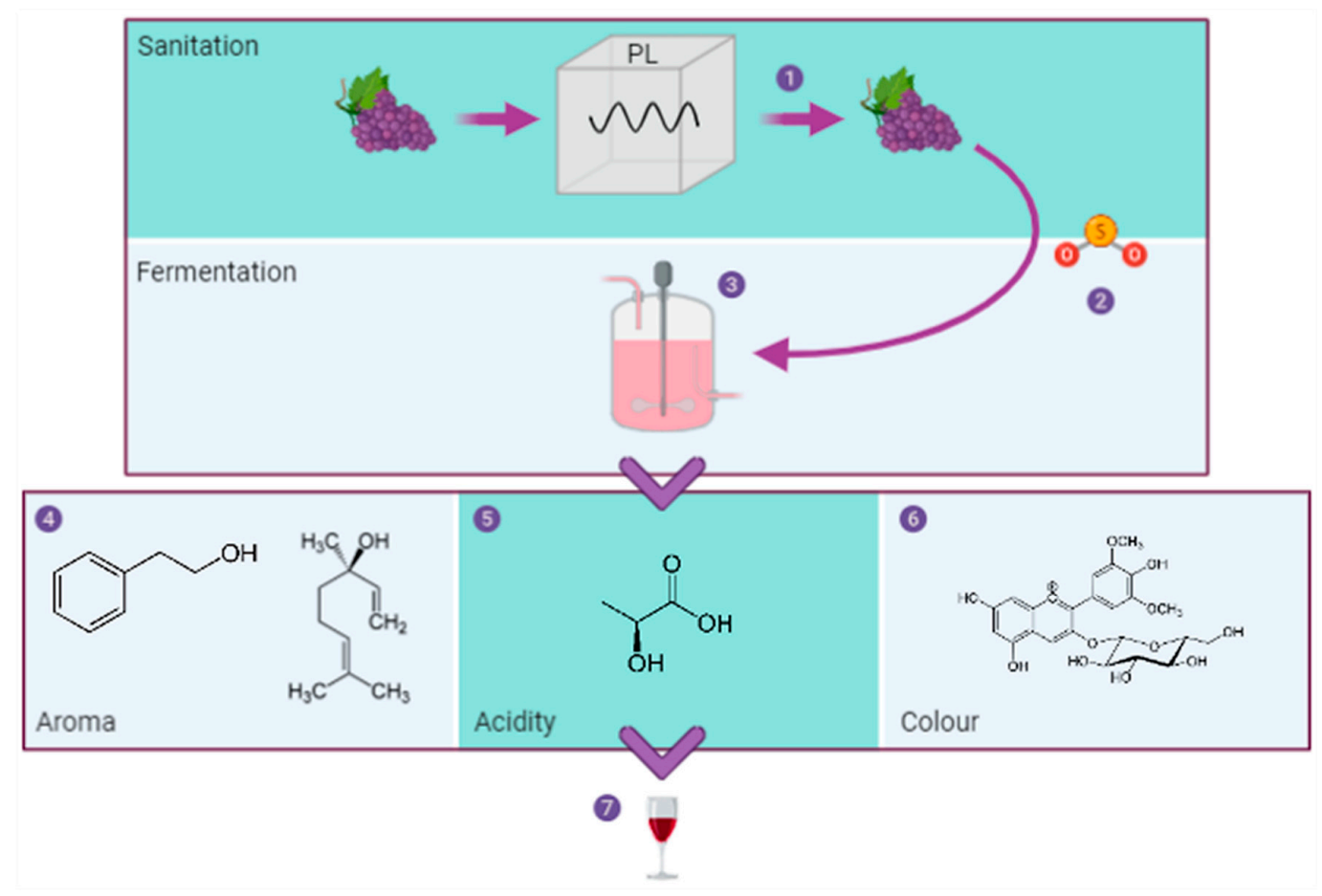

Figure 5. Summary of the potential benefits of using PL sanitation on grapes in the winemaking industry. (1) Inactivation or elimination of microbial population, (2) less usage of $\mathrm{SO}_{2}$, (3) use of selected non-Saccharomyces yeasts, (4) enhance aroma profile, (5) modulate organic acidity, (6) increase pigment extraction and (7) gain freshness in wines towards customer preferences. 


\section{Conclusions}

Pulsed light sanitation of grapes intended for use in winemaking production at the industrial scale may become affordable in the coming years. The efficiency of the UV-C light fraction of PL in inactivating microorganisms, the possibility of reducing the use of $\mathrm{SO}_{2}$ to process and store musts, and the relatively low energy cost would make its deployment possible. Among the benefits observed in laboratory trials is the use of selected non-Saccharomyces strains from commercial traders to produce wines with enhanced organoleptic profiles in accordance with customers' demands and fulfilling quality control requirements.

One further challenge in the use of PL as non-thermal sanitation technology in the winemaking industry will be the design of systems able to process grape musts. The difficulties in achieving this will be to deal with a product with variable viscosity and with inhomogeneous particle size distribution. The energy needed for non-transparent liquids with low transmittance capacity and the scale-up design are issues that still have to be addressed. In this matter, the use of PL treatment to avoid the establishment of spoilage yeast during wine-making has to be evaluated with the use of special $1 \mathrm{~mm}$ width quartz cells. Additionally, further studies have to be performed in order to determine the impact that different PL doses have on the antioxidant capacity and the phenolic content of wines, as well as the effect of the treatment on other phenolic volatile compounds responsible for the wine aroma.

Author Contributions: A.S. drafted the manuscript; C.E. drafted the manuscript; I.L. supported the drafting of the manuscript and revise the manuscript; J.M.d.F. revised and corrected the manuscript; C.G. corrected the language and revised the manuscript; and A.M. revised the manuscript. All authors have read and agreed to the published version of the manuscript.

Funding: This research was funded by Ministerio de Ciencia, Innovación y Universidades grant number [RTI2018-096626-B-I00].

Conflicts of Interest: The authors declare no conflict of interest.

\section{References}

1. Barbosa-Canovas, G.V.; Schaffner, D.W.; Pierson, M.D.; Zhang, Q.H. Pulsed Light Technology. J. Food Sci. 2000, 65, 82-85. [CrossRef]

2. Johan, L.; Nilsson, A.; Gb, S.; Lefort, L.; Fr, L.; Hugh, J.; Price, V.; Gb, C. Pulsed light sources. U.S. Patent US6917631B2, 12 July 2005.

3. Unni, L.E.; Chauhan, O.P. Use of Pulsed Light in Food Processing. In Non-Thermal Processing of Foods; Chauhan, O.P., Ed.; CRC Press: Boca Raton, FL, USA, 2019; pp. 173-188.

4. Kirkpatrick, A.R. Method involving pulsed light processing of semiconductor devices. U.S. Patent US4151008, 24 April 1979.

5. Ryu, J.; Kim, H.S.; Hahn, H.T. Reactive sintering of copper nanoparticles using intense pulsed light for printed electronics. J. Electron. Mater. 2011, 40, 42-50. [CrossRef]

6. Babilas, P.; Schreml, S.; Szeimies, R.M.; Landthaler, M. Intense pulsed light (IPL): A review. Lasers Surg. Med. 2010, 42, 93-104. [CrossRef] [PubMed]

7. Negishi, K.; Tezuka, Y.; Kushikata, N.; Wakamatsu, S. Photorejuvenation for Asian skin by intense pulsed light. Dermatol. Surg. 2001, 27, 627-632. [PubMed]

8. Goldberg, D.J. New collagen formation after dermal remodeling with an intense pulsed light source. J. Cutan. Laser Ther. 2000, 2, 59-61. [CrossRef] [PubMed]

9. Schroeter, C.A.; Below, S.H.-V.; Neumann, H.A.M. Effective treatment of rosacea using intense pulsed light systems. Dermatol. Surg. 2005, 31, 1285-1289. [CrossRef]

10. Angermeier, M.C. Treatment of facial vascular lesions with intense pulsed light. J. Cosmet. Laser Ther. 1999, 1, 95-100. [CrossRef]

11. Hernández-Pérez, E.; Colombo-Charrier, E.; Valencia-Ibiett, E. Intense pulsed light in the treatment of striae distensae. Dermatol. Surg. 2002, 28, 1124-1130.

12. Gold, M.H.; Bell, M.W.; Foster, T.D.; Street, S. Long-term epilation using the EpiLight broad band, intense pulsed light Hair Removal System. Dermatol. Surg. 1997, 23, 909-913. [CrossRef] 
13. Pollock, A.M.; Singh, A.P.; Ramaswamy, H.S.; Ngadi, M.; Singh, P. Pulsed light destruction kinetics of L. monocytogenes. LWT-Food Sci. Technol. 2017, 84, 114-121. [CrossRef]

14. MacGregor, S.J.; Rowan, N.J.; McIlvaney, L.; Anderson, J.G.; Fouracre, R.A.; Farish, O. Light inactivation of food-related pathogenic bacteria using a pulsed power source. Lett. Appl. Microbiol. 1998, 27, 67-70. [CrossRef] [PubMed]

15. Rowan, N.J.; MacGregor, S.J.; Anderson, J.G.; Fouracre, R.A.; McIlvaney, L.; Farish, O. Pulsed-Light Inactivation of Food-Related Microorganisms. Appl. Environ. Microbiol. 1999, 65, 1312-1315. [CrossRef] [PubMed]

16. Elmnasser, N.; Guillou, S.; Leroi, F.; Orange, N.; Bakhrouf, A.; Federighi, M. Pulsed-light system as a novel food decontamination technology: A review. Can. J. Microbiol. 2007, 53, 813-821. [CrossRef]

17. Brown, A.C. Understanding Food-Principles and Preparation, 3rd ed.; Thomson Wadsworth: Belmont, CA, USA, 2008; ISBN 9780495107453.

18. Song, K.; Taghipour, F.; Mohseni, M. Microorganisms inactivation by wavelength combinations of ultraviolet light-emitting diodes (UV-LEDs). Sci. Total Environ. 2019, 665, 1103-1110. [CrossRef] [PubMed]

19. Gómez-López, V.M.; Ragaert, P.; Debevere, J.; Devlieghere, F. Pulsed light for food decontamination: A review. Trends Food Sci. Technol. 2007, 18, 464-473. [CrossRef]

20. Wiktor, A.; Mandal, R.; Singh, A.; Singh, A.P. Pulsed Light treatment below a Critical Fluence. Foods 2019, 8,1-13.

21. Martín-belloso, O.; Soliva-fortuny, R.; Elez-Martínez, P.; Marsellés-Fontanet, R.; Vega-mercado, H. Non-thermal Processing Technologies. In Food Safety Management; Motarjemi, Y., Lelieveld, H., Eds.; Academic Press Inc.: London, UK, 2014; pp. 443-465. ISBN 9780123815040.

22. Rowan, N.J. Pulsed light as an emerging technology to cause disruption for food and adjacent industries-Quo vadis? Trends Food Sci. Technol. 2019, 88, 316-332. [CrossRef]

23. Wekhof, A. Disinfection with flash lamps. PDA J. Pharm. Sci. Technol. 2000, 54, 264-276.

24. Kumar, P.; Han, J.H. Packaging materials for non-thermal processing of food and beverages. In Emerging Food Packaging Technologies; Yan, K., Lee, D.S., Eds.; Woodhead Publishing: Oxford, UK, 2012; pp. 323-334.

25. Morris, C.; Brody, A.L.; Wicker, L. Non-Thermal Food Processing/Preservation Technologies: A Review with Packaging Implications. Packag. Tech. Sci. 2007, 20, 275-286. [CrossRef]

26. Agüero, M.V.; Jagus, R.J.; Martín-Belloso, O.; Soliva-Fortuny, R. Surface decontamination of spinach by intense pulsed light treatments: Impact on quality attributes. Postharvest Biol. Technol. 2016, 121, 118-125. [CrossRef]

27. Llano, K.R.A.; Marsellés-Fontanet, A.R.; Martín-Belloso, O.; Soliva-Fortuny, R. Impact of pulsed light treatments on antioxidant characteristics and quality attributes of fresh-cut apples. Innov. Food Sci. Emerg. Technol. 2016, 33, 206-215. [CrossRef]

28. Valdivia-Nájar, C.G.; Martín-Belloso, O.; Giner-Seguí, J.; Soliva-Fortuny, R. Modeling the Inactivation of Listeria innocua and Escherichia coli in Fresh-Cut Tomato Treated with Pulsed Light. Food Bioprocess. Technol. 2017, 10, 266-274. [CrossRef]

29. Leng, J.; Mukhopadhyay, S.; Sokorai, K.; Ukuku, D.O.; Fan, X.; Olanya, M.; Juneja, V. Inactivation of Salmonella in cherry tomato stem scars and quality preservation by pulsed light treatment and antimicrobial wash. Food Control. 2020, 110, 107005. [CrossRef]

30. Ignat, A.; Manzocco, L.; Maifreni, M.; Bartolomeoli, I.; Nicoli, M.C. Surface decontamination of fresh-cut apple by pulsed light: Effects on structure, colour and sensory properties. Postharvest Biol. Technol. 2014, 91, 122-127. [CrossRef]

31. Tao, T.; Ding, C.; Han, N.; Cui, Y.; Liu, X.; Zhang, C. Evaluation of pulsed light for inactivation of foodborne pathogens on fresh-cut lettuce: Effects on quality attributes during storage. Food Packag. Shelf Life 2019, 21, 100358. [CrossRef]

32. Keklik, N.M.; Demirci, A.; Puri, V.M. Decontamination of unpackaged and vacuum-packaged boneless chicken breast with pulsed ultraviolet light. Poult. Sci. 2010, 89, 570-581. [CrossRef]

33. $\mathrm{Xu}, \mathrm{W}$; $\mathrm{Wu}, \mathrm{C}$. The impact of pulsed light on decontamination, quality, and bacterial attachment of fresh raspberries. Food Microbiol. 2016, 57, 135-143. [CrossRef]

34. Aguiló-Aguayo, I.; Charles, F.; Renard, C.M.G.C.; Page, D.; Carlin, F. Pulsed light effects on surface decontamination, physical qualities and nutritional composition of tomato fruit. Postharvest Biol. Technol. 2013, 86, 29-36. [CrossRef] 
35. Aguiló-Aguayo, I.; Oms-Oliu, G.; Martín-Belloso, O.; Soliva-Fortuny, R. Impact of pulsed light treatments on quality characteristics and oxidative stability of fresh-cut avocado. LWT-Food Sci. Technol. 2014, 59, 320-326. [CrossRef]

36. Valdivia-Nájar, C.G.; Martín-Belloso, O.; Soliva-Fortuny, R. Impact of pulsed light treatments and storage time on the texture quality of fresh-cut tomatoes. Innov. Food Sci. Emerg. Technol. 2018, 45, 29-35. [CrossRef]

37. Taştan, Ö.; Pataro, G.; Donsì, F.; Ferrari, G.; Baysal, T. Decontamination of fresh-cut cucumber slices by a combination of a modified chitosan coating containing carvacrol nanoemulsions and pulsed light. Int. J. Food Microbiol. 2017, 260, 75-80. [CrossRef] [PubMed]

38. Ramos-Villarroel, A.Y.; Martín-Belloso, O.; Soliva-Fortuny, R. Combined effects of malic acid dip and pulsed light treatments on the inactivation of Listeria innocua and Escherichia coli on fresh-cut produce. Food Control. 2015, 52, 112-118. [CrossRef]

39. Huang, Y.; Ye, M.; Cao, X.; Chen, H. Pulsed light inactivation of murine norovirus, Tulane virus, Escherichia coli O157:H7 and Salmonella in suspension and on berry surfaces. Food Microbiol. 2017, 61, 1-4. [CrossRef] [PubMed]

40. Cao, X.; Huang, R.; Chen, H. Evaluation of pulsed light treatments on inactivation of Salmonella on blueberries and its impact on shelf-life and quality attributes. Int. J. Food Microbiol. 2017, 260, 17-26. [CrossRef] [PubMed]

41. Xu, W.; Chen, H.; Wu, C. Salmonella and Escherichia coli O157:H7 inactivation, color, and bioactive compounds enhancement on raspberries during frozen storage after decontamination using new formula sanitizer washing or pulsed light. J. Food Prot. 2016, 79, 1107-1114. [CrossRef] [PubMed]

42. Xu, W.; Chen, H.; Huang, Y.; Wu, C. Decontamination of Escherichia coli O157: H7 on green onions using pulsed light (PL) and PL-surfactant-sanitizer combinations. Int. J. Food Microbiol. 2013, 166, 102-108. [CrossRef]

43. Fernández, M.; Hospital, X.F.; Cabellos, C.; Hierro, E. Effect of pulsed light treatment on Listeria inactivation, sensory quality and oxidation in two varieties of Spanish dry-cured ham. Food Chem. 2020, 316, 126294. [CrossRef]

44. Koch, F.; Wiacek, C.; Braun, P.G. Pulsed light treatment for the reduction of Salmonella Typhimurium and Yersinia enterocolitica on pork skin and pork loin. Int. J. Food Microbiol. 2019, 292, 64-71. [CrossRef]

45. Vaclavik, V.A.; Christian, E.W. Essentials of Food Science, 4th ed.; Heldman, D.R., Ed.; Springer: New York, NY, USA, 2008; Volume 45, ISBN 9781461491378.

46. Marriott, N.G.; Gravani, R.B. Principles of Food Sanitation, 5th ed.; Springer: New York, NY, USA, 2006; ISBN 9780387250250.

47. Mahendran, R.; Ramanan, K.R.; Barba, F.J.; Lorenzo, J.M.; López-Fernández, O.; Munekata, P.E.S.; Roohinejad, S.; Sant'Ana, A.S.; Tiwari, B.K. Recent advances in the application of pulsed light processing for improving food safety and increasing shelf life. Trends Food Sci. Technol. 2019, 88, 67-79. [CrossRef]

48. Oms-Oliu, G.; Martín-Belloso, O.; Soliva-Fortuny, R. Pulsed light treatments for food preservation. A review. Food Bioprocess. Technol. 2010, 3, 13-23. [CrossRef]

49. Guerrero-Beltrán, J.Á.; Welti-Chanes, J.; Barbosa-Cánovas, G.V. Ultraviolet-C light processing of grape, cranberry and grapefruit juices to inactivate Saccharomyces cerevisiae. J. Food Process. Eng. 2009, 32, 916-932. [CrossRef]

50. Valero, A.; Begum, M.; Leong, S.L.; Hocking, A.D.; Ramos, A.J.; Sanchis, V.; Marín, S. Effect of germicidal UVC light on fungi isolated from grapes and raisins. Lett. Appl. Microbiol. 2007, 45, 238-243. [CrossRef] [PubMed]

51. Pala, Ç.U.; Toklucu, A.K. Effects of UV-C Light Processing on Some Quality Characteristics of Grape Juices. Food Bioprocess. Technol. 2013, 6, 719-725. [CrossRef]

52. Escott, C.; Vaquero, C.; del Fresno, J.M.; Bañuelos, M.A.; Loira, I.; Han, S.; Bi, Y.; Morata, A.; Suárez-Lepe, J.A. Pulsed light effect in red grape quality and fermentation. Food Bioprocess. Technol. 2017, 10, 1540-1547. [CrossRef]

53. Marquenie, D.; Michiels, C.W.; Van Impe, J.F.; Schrevens, E.; Nicolaï, B.N. Pulsed white light in combination with UV-C and heat to reduce storage rot of strawberry. Postharvest Biol. Technol. 2003, 28, 455-461. [CrossRef]

54. Fava, J.; Hodara, K.; Nieto, A.; Guerrero, S.; Alzamora, S.M.; Castro, M.A. Structure (micro, ultra, nano), color and mechanical properties of Vitis labrusca L. (grape berry) fruits treated by hydrogen peroxide, UV-C irradiation and ultrasound. Food Res. Int. 2011, 44, 2938-2948. [CrossRef] 
55. Morata, A.; Loira, I.; Vejarano, R.; González, C.; Callejo, M.J.; Suárez-Lepe, J.A. Emerging preservation technologies in grapes for winemaking. Trends Food Sci. Technol. 2017, 67, 36-43. [CrossRef]

56. Morata, A.; Loira, I.; Guamis, B.; Raso, J.; del Fresno, J.M.; Escott, C.; Bañuelos, M.A.; Álvarez, I.; Tesfaye, W.; González, C.; et al. Emerging technologies to increase extraction, control microorganisms, and reduce $\mathrm{SO} 2$. In Winemaking-Stabilization, Aging Chemistry and Biochemistry; Cosme, F., Ed.; IntechOpen: London, UK, 2020; pp. 1-20.

57. Canonico, L.; Comitini, F.; Oro, L.; Ciani, M. Sequential Fermentation with Selected Immobilized Non-Saccharomyces Yeast for Reduction of Ethanol Content in Wine. Front. Microbiol. 2016, 7, 278-289. [CrossRef]

58. Contreras, A.; Hidalgo, C.; Schmidt, S.; Henschke, P.A.; Curtin, C.; Varela, C. The application of non-Saccharomyces yeast in fermentations with limited aeration as a strategy for the production of wine with reduced alcohol content. Int. J. Food Microbiol. 2015, 205, 7-15. [CrossRef]

59. Loira, I.; Morata, A.; González, C.; Suárez-Lepe, J.A. Selection of Glycolytically Inefficient Yeasts for Reducing the Alcohol Content of Wines from Hot Regions. Food Bioprocess. Technol. 2012, 5, 2787-2796. [CrossRef]

60. Bisson, L.F.; Joseph, C.M.L.; Domizio, P. Yeasts. In Biology of Microorganisms on Grapes, in Must and in Wine; König, H., Unden, G., Fröhlich, J., Eds.; Springer International Publishing AG: Cham, Switzerland, 2017; pp. 65-102. ISBN 9783319600208.

61. Rêgo, E.S.B.; Rosa, C.A.; Freire, A.L.; Machado, A.M.d.R.; Gomes, F.d.C.O.; Costa, A.S.P.d.; Mendonça, M.d.C.; Hernández-Macedo, M.L.; Padilha, F.F. Cashew wine and volatile compounds produced during fermentation by non-Saccharomyces and Saccharomyces yeast. LWT 2020, 126, 109291. [CrossRef]

62. Del Fresno, J.M.; Morata, A.; Loira, I.; Bañuelos, M.A.; Escott, C.; Benito, S.; Chamorro, C.G.; Suárez-Lepe, J.A. Use of non-Saccharomyces in single-culture, mixed and sequential fermentation to improve red wine quality. Eur. Food Res. Technol. 2017, 243, 2175-2185. [CrossRef]

63. Liu, P.T.; Lu, L.; Duan, C.Q.; Yan, G.L. The contribution of indigenous non-Saccharomyces wine yeast to improved aromatic quality of Cabernet Sauvignon wines by spontaneous fermentation. LWT-Food Sci. Technol. 2016, 71, 356-363. [CrossRef]

64. Morata, A.; Escott, C.; Loira, I.; del Fresno, J.M.; González, C.; Suárez-Lepe, J.A. Influence of Saccharomyces and non-Saccharomyces Yeasts in the Formation of Pyranoanthocyanins and Polymeric Pigments during Red Wine Making. Molecules 2019, 24, 4490. [CrossRef] [PubMed]

65. Suárez-Lepe, J.A.; Morata, A. New trends in yeast selection for winemaking. Trends Food Sci. Technol. 2012, 23, 39-50. [CrossRef]

66. Pateraki, C.; Paramithiotis, S.; Doulgeraki, A.I.; Kallithraka, S.; Kotseridis, Y.; Drosinos, E.H. Effect of sulfur dioxide addition in wild yeast population dynamics and polyphenolic composition during spontaneous red wine fermentation from Vitis vinifera cultivar Agiorgitiko. Eur. Food Res. Technol. 2014, 239, 1067-1075. [CrossRef]

67. Martins, V.; Lopez, R.; Garcia, A.; Teixeira, A.; Gerós, H. Vineyard calcium sprays shift the volatile profile of young red wine produced by induced and spontaneous fermentation. Food Res. Int. 2020, 131, 108983. [CrossRef] [PubMed]

68. Morata, A.; Escott, C.; Bañuelos, M.A.; Loira, I.; Del Fresno, J.M.; González, C.; Suárez-lepe, J.A. Contribution of non-Saccharomyces yeasts to wine freshness. A review. Biomolecules 2020, 10, 34. [CrossRef]

69. Delsart, C.; Grimi, N.; Boussetta, N.; Sertier, C.M.; Ghidossi, R.; Peuchot, M.M.; Vorobiev, E. Comparison of the effect of pulsed electric field or high voltage electrical discharge for the control of sweet white must fermentation process with the conventional addition of sulfur dioxide. Food Res. Int. 2015, 77, 718-724. [CrossRef]

70. Mozell, M.R.; Thachn, L. The impact of climate change on the global wine industry: Challenges \& solutions. Wine Econ. Policy 2014, 3, 81-89.

71. Keller, M. Managing grapevines to optimise fruit development in a challenging environment: A climate change primer for viticulturists. Aust. J. Grape Wine Res. 2010, 16, 56-69. [CrossRef]

72. Portu, J.; López, R.; Baroja, E.; Santamaría, P.; Garde-Cerdán, T. Improvement of grape and wine phenolic content by foliar application to grape-vine of three different elicitors: Methyl jasmonate, chitosan, and yeast extract. Food Chem. 2016, 201, 213-221. [CrossRef] [PubMed] 
73. Pataro, G.; Sinik, M.; Capitoli, M.M.; Donsì, G.; Ferrari, G. The influence of post-harvest UV-C and pulsed light treatments on quality and antioxidant properties of tomato fruits during storage. Innov. Food Sci. Emerg. Technol. 2015, 30, 103-111. [CrossRef]

74. Zhang, B.-Q.; Shen, J.-Y.; Duan, C.-Q.; Yan, G.-L. Use of indigenous Hanseniaspora vineae and Metschnikowia pulcherrima co-fermentation with Saccharomyces cerevisiae to improve the aroma diversity of Vidal Blanc icewine. Front. Microbiol. 2018, 9, 2303. [CrossRef]

75. Martin, V.; Giorello, F.; Fariña, L.; Minteguiaga, M.; Salzman, V.; Boido, E.; Aguilar, P.S.; Gaggero, C.; Dellacassa, E.; Mas, A.; et al. De novo synthesis of benzenoid compounds by the yeast Hanseniaspora vineae increases the flavor diversity of wines. J. Agric. Food Chem. 2016, 64, 4574-4583. [CrossRef] [PubMed]

76. Giorello, F.; Valera, M.J.; Martin, V.; Parada, A.; Salzman, V.; Camesasca, L.; Fariña, L.; Boido, E.; Medina, K.; Dellacassa, E.; et al. Genomic and transcriptomic basis of Hanseniaspora vineae's impact on flavor diversity and wine quality. Appl. Environ. Microbiol. 2019, 85, 1-43.

77. Senses-Ergul, S.; Ágoston, R.; Belák, Á.; Deák, T. Characterization of some yeasts isolated from foods by traditional and molecular tests. Int. J. Food Microbiol. 2006, 108, 120-124. [CrossRef] [PubMed]

78. Morata, A.; Loira, I.; Tesfaye, W.; Bañuelos, M.; González, C.; Lepe, J.S. Lachancea thermotolerans applications in wine technology. Fermentation 2018, 4, 53. [CrossRef]

79. Lucio, O.; Pardo, I.; Heras, J.M.; Krieger-Weber, S.; Ferrer, S. Use of starter cultures of Lactobacillus to induce malolactic fermentation in wine. Aust. J. Grape Wine Res. 2017, 23, 15-21. [CrossRef]

80. Krieger-Weber, S.; Heras, J.M.; Suarez, C. Lactobacillus plantarum, a New Biological Tool to Control Malolactic Fermentation: A Review and an Outlook. Beverages 2020, 6, 23. [CrossRef]

81. Morata, A.; Bañuelos, M.A.; López, C.; Song, C.; Vejarano, R.; Loira, I.; Palomero, F.; Lepe, J.A.S. Use of fumaric acid to control $\mathrm{pH}$ and inhibit malolactic fermentation in wines. Food Addit. Contam.-Part A Chem. Anal. Control. Expo. Risk Assess. 2020, 37, 228-238. [CrossRef] [PubMed]

82. Morata, A.; Bañuelos, M.A.; Vaquero, C.; Loira, I.; Cuerda, R.; Palomero, F.; González, C.; Suárez-Lepe, J.A.; Wang, J.; Han, S.; et al. Lachancea thermotolerans as a tool to improve $\mathrm{pH}$ in red wines from warm regions. Eur. Food Res. Technol. 2019, 245, 885-894. [CrossRef]

83. Escott, C.; Morata, A.; Loira, I.; Tesfaye, W.; Suarez-Lepe, J.A. Characterization of polymeric pigments and pyranoanthocyanins formed in microfermentations of non-Saccharomyces yeasts. J. Appl. Microbiol. 2016, 121, 1346-1356. [CrossRef] [PubMed]

84. Escott, C.; Del Fresno, J.M.; Loira, I.; Morata, A.; Tesfaye, W.; González, C.; Suárez-Lepe, J.A. Formation of polymeric pigments in red wines through sequential fermentation of flavanol-enriched musts with non-Saccharomyces yeasts. Food Chem. 2018, 239, 975-983. [CrossRef] [PubMed]

85. Oliveira, J.; de Freitas, V.; Mateus, N. Polymeric Pigments in Red Wines. In Red Wine Technology; Morata, A., Ed.; Academic Press: London, UK, 2019; pp. 207-218, ISBN 9780128144008. 